University of Rhode Island

DigitalCommons@URI

Open Access Master's Theses

1991

\title{
TENANT ORGANIZATION AT UNIVERSITY HEIGHTS
}

Michael J. Fawcett

University of Rhode Island

Follow this and additional works at: https://digitalcommons.uri.edu/theses

\section{Recommended Citation}

Fawcett, Michael J., "TENANT ORGANIZATION AT UNIVERSITY HEIGHTS" (1991). Open Access Master's Theses. Paper 404.

https://digitalcommons.uri.edu/theses/404

This Thesis is brought to you for free and open access by DigitalCommons@URI. It has been accepted for inclusion in Open Access Master's Theses by an authorized administrator of DigitalCommons@URI. For more information, please contact digitalcommons-group@uri.edu. 
TENANT ORGANIZATION AT UNIVERSITY HEIGHTS

BY

MICHAEL J. FAWCETT

\author{
A RESEARCH PROJECT SUBMITTED IN \\ PARTIAL FULFILLMENT OF THE REQUIREMENTS \\ FOR THE DEGREE OF MASTER OF COMMUNITY PLANNING \\ UNIVERSITY OF RHODE ISIAND \\ 1991
}


MASTER OF COMMUNITY PLANNING

RESEARCH PROJECT OF

MICHAEL J. EAWCETT

APPROVED :

Major Professor

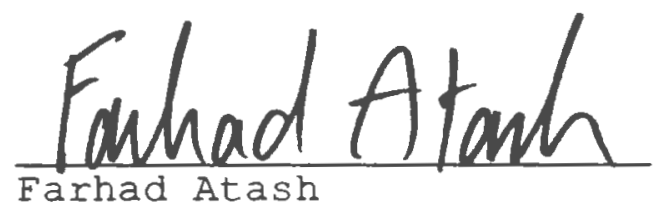

ACKNOWLEDGED :

Director

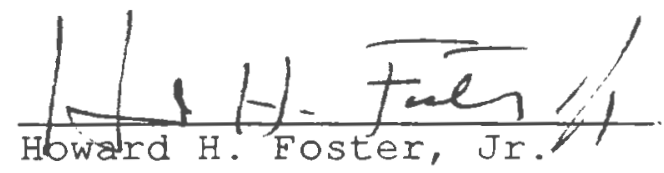




\section{ABSTRACT}

The tenants of University Heights, a 350-unit mixedincome, housing development in Providence, Rhode Island, organized in response to the prepayment of Section 221 (d) (3) mortgages on some 48 units, causing the displacement of 35 families. Their overwhelming success was analyzed in terms of its applicability to several frameworks provided by studies of community organization and public participation. This study has identified and explored two key elements of a successful tenant organization--leadership and cohesion.

Chapter one sets forth the goals and objectives of the study, which mainly include determining the significance of these elements as part of the organization's formula for success.

Chapters Two and Three provide the background for both University Heights and the tenant organization, while Chapters Four and Five apply the two elements two frameworks provided by Wireman's seven conditions for "good participation" and Edelstein and Wandersman's "tenant functions"--the role collectively played by tenants as an organization.

Chapter Six will summarize the applicability of these elements to the above described frameworks and draw some general conclusions, provide an overview of lessons learned from the tenants of University Heights, and identify some of the steps that tenants of threatened subsidized rental housing might find of interest. 
I am grateful for the guidance and assistance of Dr. Farhad Atash in this and other research projects. Dr. Atash's wisdom and kindness had everything to do with the successful completion of this project and his efforts did not go unnoticed.

I would also like to express my gratitude to Chuck Gricus, whose advice and friendship during the past year will always be remembered.

In addition, I am grateful for the comments provided by Marjorie Jensen, whose housing expertise guided me through a number of challenges that arose during the course of the semester.

The completion of this project is also due to the assistance of Mr. Harry Platt, the remarkable president of the Association of Tenants of University Heights; as well as Mr. Michael Milito of the Community Builders. Their assistance is greatly appreciated.

Finally, I would like to express my gratitude and affection for Alison, who made the last year a fantastic one. I am looking forward to many more like it. 
TABLE OF CONTENTS

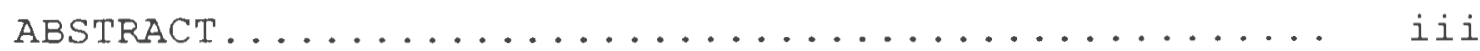

ACKNOWLEDGEMENTS ....................... iv

TABLE OF CONTENTS..................... v

Chapters

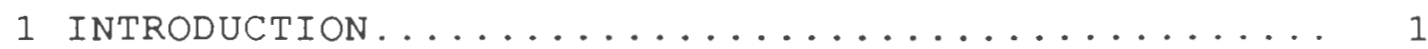

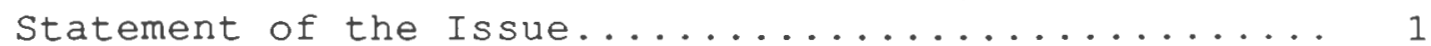

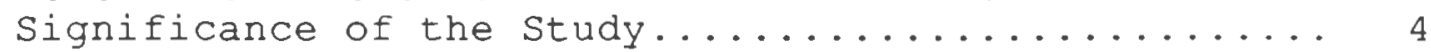

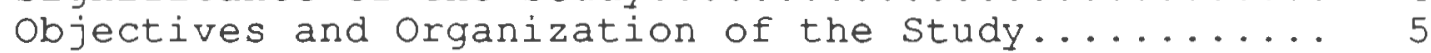

The Elements: An Overview................... 7

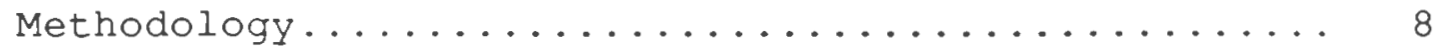

2 HISTORY AND BACKGROUND..................... 10

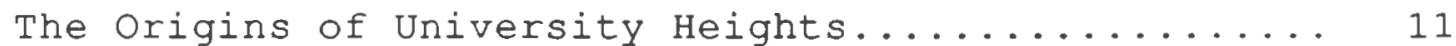

The Emergence of ATUH..................... 14

Need for Technical Assistance is Recognized......... 15

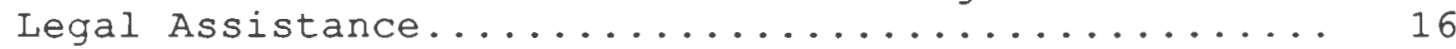

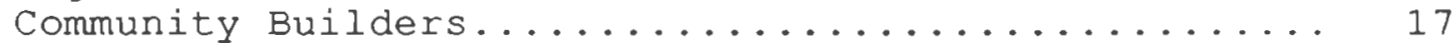

Financing Plans are Initiated................. 18

State and Local Government Involvement Begins...... 19

Ownership of University Heights.............. 20

3 SUBSIDIZED RENTAL HOUSING IN RHODE ISLAND......... 21

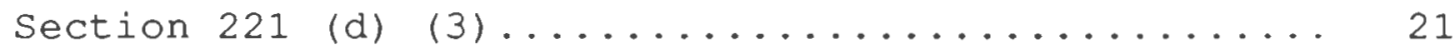

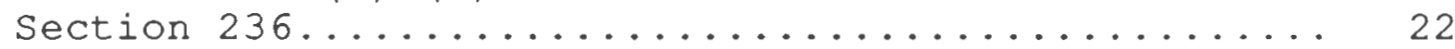

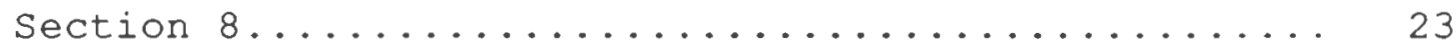

Changes in Housing Policy Under the Reagan

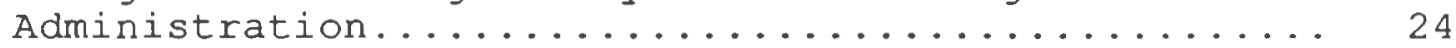

Potential Impacts of Prepayment on Rhode Island.... 26

4 STRONG LEADERSHIP..................... 28

Leadership in Tenant Organization: Why is it

Important?........................ 28

Application of Wireman's Conditions to the Case

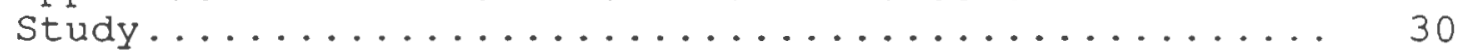

5 TENANT COHESION......................... 40

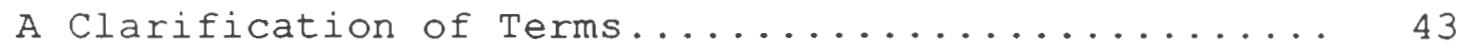

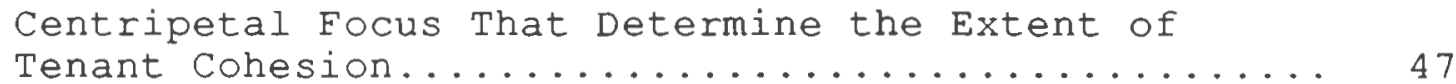

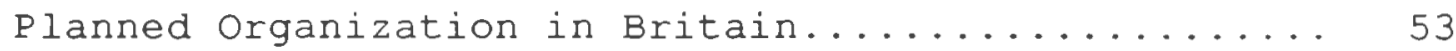

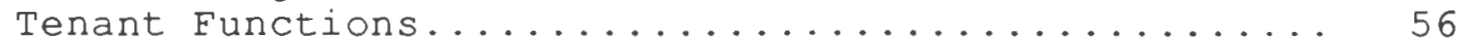




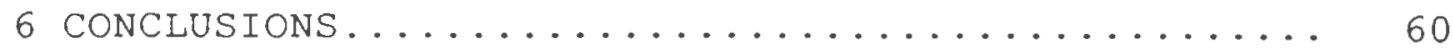

Goals Addressed by the Study................. 61

BI BLIOGRAPHY 


\title{
CHAPTER ONE
}

\section{INTRODUCTION}

\begin{abstract}
"We hope our experience will encourage other tenant groups facing the same threats we faced to take action to protect their communities"
\end{abstract}

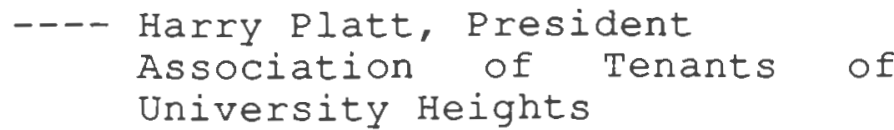

\section{Statement of the Issue}

Any discussion of affordable housing in Rhode Island will document the sharp rise in home prices and simultaneous stagnation of income that has taken place since the 1970 s (RIHMFC, 1990). This phenomenon has been accompanied by the voting record of the U.S. Congress throughout the 1980s, which voted to double military spending while cutting funds for lowincome housing by 82 percent (Jobs With Peace Campaign, 1990).

What is equally astounding, however, is the number of nonprofit development activities that have filled the gap left by the federal government's retreat from housing assistance programs. During this period, the number of community-based organizations, especially in the economically depressed Northeast, has increased tenfold. "According to a National Congress for Community Economic Development survey published in March, 1989, there are now 1,500 to 2,000 such organizations that have completed at least one housing, commercial industrial, or business enterprise development 
project--and 35 percent are in New England states, New York, and Pennsylvania" (New England Real Estate Magazine, 1989).

Some, but not many of these $\mathrm{CBO}$ s have responded to one of the more troubling dimensions of the nation's housing crisis: the imminent threat to the nation's 1.9 million privatelyowned, federally-assisted, low income rental units under the Section 8, section 236 and section 221 (d) (3) programs (Chung, 1988). Many of these units were constructed or rehabilitated with subsidized loans provided by the Department of Housing and Urban Development (HUD) under the condition that, after 20 years, the owner of the development may prepay the mortgage and convert the units within it to market-rate apartments. As these terms approach expiration--between 470,000 and 577,000 units by 1996 nationwide--the present housing crisis will only worsen (Chung, 1988).

As it is now apparent that CBOs are taking on a central role in the provision of affordable housing, it seems possible that these two trends; the threat to the nation's rental housing stock and the large-scale emergence of CBOs; can be fused together. If CBOs were formed to organize tenants of threatened subsidized housing, two very desirable outcomes could result; first, the alleviation of the nation's affordable housing crisis and second, the empowerment of lower-income tenants of privately-owned subsidized units. Although not much evidence proves that this alternative has become widespread, there are several indications that tenant 
organization and empowerment through ownership are possible. First, the emergence of the "Kennedy Bill" or the "Low Income Housing Preservation and Resident Homeownership Act of 1990" has provided for assumption of ownership by tenants with a legal basis. The Act provides "tenant organizations, nonprofit sponsors, and public agencies with preemptive purchase rights with respect to any property offered for voluntary or mandatory sale" (Edson, 1990). In other words, if the owner of a housing development wants to sell for the purpose of either condominium conversion or upgrading to market rate, according to the Kennedy Bill, either the tenants, a nonprofit sponsor, or public agency will have the right to buy the development before it is offered for sale to a developer.

Secondly, tenant ownership of a rental development has become reality recently in Providence, Rhode Island, where University Heights, a 349-unit mixed income development constructed under the Urban Renewal program of the mid-1960s, was purchased by the Association of Tenants of University Heights (ATUH), a CBO which formed in response to the displacement of some 35 lower income tenants after the prepayment of mortgages on their apartments.

Finally, a combination of other factors indicate that tenants can, in fact, respond effectively if their tenure in a subsidized housing development is threatened. These include the initiation of a lawsuit such as that instituted by ATUH 
against the development's former owners, based on an alleged violation of Title VII of the Fair Housing Act of 1968 . Although the lawsuit was not carried out, it indicates that tenant organizations have a number of alternatives in defending themselves from eviction.

In addition, $\mathrm{ATUH}^{\prime}$ s efforts are already being simulated by tenant groups in other New England communities, although their efforts have not yet reached fruition (Milito, 1991).

Another factor is the recognition of tenant ownership as an alternative at the state level, and its subsequent inclusion as a policy option by the Rhode Island Housing and Mortgage Finance Corporation (RIHMFC), also referred to as Rhode Island Housing. Rhode Island Housing is a public corporation that provides financial and program support in the development and preservation of affordable housing opportunities for low and moderate income groups (RIHMFC, 1990). The Corporation has acknowledged Rhode Island's share of the crisis--approximately 17,453 units at risk statewide-and has addressed it in a recent report.

\section{Significance of the study}

This study will determine the feasibility of a more widespread application of ATUH's successful methods at the state level. In light of the previously-discussed crisis facing the nation's subsidized housing stock, the success story of ATUH is certainly worthy of analysis because, if 
simulated elsewhere, it could serve as a model of tenant empowerment and the mitigation of at least one dimension of affordable housing problems. The analysis contained herein is, therefore, may serve as a practical guide for tenant organizations faced with challenges similar to those faced by the Association of Tenants of University Heights.

\section{Objectives and Organization of the Study}

This analysis has been divided into two major sections-tenant leadership and tenant cohesion--each discussing the conditions that have been identified as major elements of a successful tenant organization. Prior to this, a background will be provided for both University Heights and the subsidized rental housing crisis at large. These two element merits consideration in the establishment and development of a successful $\mathrm{CBO}$ and their analysis is intended to serve as both an example of, as well as a guide to, the formation of a CBO with the purpose of acquiring funding and purchasing their places of residence from their landlords.

University Heights is unique for a number of reasons; it was made possible by the largest mortgage ever approved by Rhode Island Housing, and is the first nonprofit housing development in Rhode Island that was purchased by its tenants; it provides an excellent example of what conditions make tenant empowerment an attainable goal.

The following objectives serve as a framework around 
which this study has been constructed. All analysis contained herein has been structured around them and has been carried out to achieve their fulfillment. They are:

1. The identification of the major elements behind the successful formation of a tenant organization (or community-based organization) who have won the right to home ownership and the priveledges that come with it.

2. The utilization of identified elements (i.e. leadership and cohesion) as variables by which to evaluate the emergence, development, and eventual success of ATUH.

3. The drawing of conclusions as to what lessons can be learned from ATUH's success and how this success can be simulated in other identified developments throughout Rhode Island.

4. The identification of steps useful to potential tenant organizations based on analysis of elements and subsequent conclusions.

Since the number of nonprofit housing organizations have proliferated, they are obviously viewed as an effective tool in softening the blow, to a certain extent, of the economic downturn and housing crisis faced by the nation and, particularly, by New England. The challenges faced by these entities can therefore be identified and evaluated by an analysis of the conditions necessary for their success.

Their applicability to University Heights varies, but these elements will be assumed to be variables by which University Heights and its success will be compared. Each will be explored comprehensively to determine its place in a general hierarchy of importance in the context of University Heights. 


\section{The Elements: An Overview}

Strong Leadership

This element is essential because it is the leadership behind a tenant movement that usually initiates it. In addition, consistent leadership has been distinguished because it is consistency which distinguishes a tenant group with direction and an agenda from a tenant group devoid of accomplishment. This is particularly so of the leadership provided by Mr. Harry Platt, the President of ATUH. Aspects of tenant organization will therefore be discussed, particularly as they relate to the success of the ATUH.

Tenant or Neighborhood Cohesion

Neighborhood cohesion in the context of affordable housing development refers to the level of support provided by the community in which the development will take place. In the context of tenant acquisition of housing, however, neighborhood cohesion refers to the degree of unity a tenant group can reach in the attainment of their mutual goal: social ownership. "Social ownership refers to the operation of housing solely for resident benefit, subject to resident control, with resale for profit prohibited. Under social ownership, the rights of use ordinarily associated with home ownership will be secured and enhanced: security of tenure, privacy, and the right to modify one's living space" (Institute for Policy Studies Working Group on Housing, 1989). 
As will be discussed in the analysis of University Heights, tenant cohesion may not be a strong factor in a $\mathrm{CBO}^{\prime} \mathrm{s}$ success in purchasing their development. Participation on the neighborhood's part is, however, a major element to be considered because at least some degree of tenant support is necessary. Exactly how much support needed will be the focus of the Tenant or Neighborhood Cohesion chapter.

\section{Methodology}

This study will differ from a traditional thesis in that its methodology will not consist of the proving or disproving of a hypothesis. It will examine relevant studies, especially Edelstein and Wandersman's study of community mobilization as a reaction to toxic contamination and wireman's study of neighborhood leadership. These studies have provided the framework for the analysis of tenant cohesion and leadership.

Each were discussed in the general sense and then as they applied to the formation of ATUH. Where the points made by these studies paralleled the events that took place at University Heights, their conformance was noted and expanded upon. When the findings of these studies conflicted with the case study, the contrasts were noted.

Chapter Six will contain the summary of findings, conclusions and recommendations to tenants of potentially 
threatened rental housing developments. The methodology of this study will therefore conclude by providing the conclusions and recommendations that will satisfy the goals indicated earlier.

It is important to note that this study will contain no empirical analysis; only the compilation and analysis of relevant historical, demographic and other aspects of tenant assumption of ownwership. 


\section{CHAPTER TWO \\ HISTORY AND BACKGROUND}

What is most noteworthy about University Height's origins is the fact that it is the fulfillment of the promise that Irving Jay Fain, a Providence businessman and proponent of fair housing, made to the residents of the area over three decades ago. Fain transformed Lippitt Hill, a largely minority-populated "slum blighted area" into University Heights, "the first urban renewal project in the United States where housing financed under two separate FHA programs will be interspersed within two groups, or 'clusters' of apartment structures" serving as "a demonstration to Providence and America that people of many backgrounds can live together" (Fawcett, 1964).

Because Lippitt Hill was completely cleared and replaced as a neighborhood by University Heights, the following historical overview will span back only three decades. Any data pertaining to previous events within the study area are irrelevant.

In addition to the origins of University Heights, this chapter will also trace the origins of ATUH and discuss its development and eventual success as a tenant organization.

What is especially significant is the full circle that has taken place in the development's purpose. The original goals of Irving Jay Fain; the retention of a racially and 
economically mixed group of residents in the neighborhood, were threatened by prepayment when some units became eligible in the mid-1980s. The actions of ATUH brought University Heights' true purpose back to its tenants. As ATUH President Harry Platt stated: "We [will] all go on paying rent like we used to. There will not be any condominiums... and there are 150 [low income units] like there were when Irving Fain built University Heights, and it's going to stay that way-economically and racially integrated. We want it that way. It's been good for us, we've all learned and benefitted from the experience, and we want it to continue indefinitely" (Dykas, 1990) .

\section{The Origins of University Heights}

Construction began on October 8, 1964 on the project, at a total of cost of $\$ 7.5$ million. The 32 -acre "Lippitt Hill redevelopment area" would eventually contain 349 housing units and a commercial development (Fawcett, 1964). The overall development was to be built in two phases, with an initial phase of 146 units completed by 1965, and the second phase consisting of the commercial center and additional units completed by 1967 (Fawcett, 1962). The eventual development would cover approximately 15 acres consisting of 22 low-rise buildings .

Prior to this, the Providence Redevelopment Agency (PRA) had determined that "90 percent of the dwelling units in the 
area were found to have at least one basic deficiency in essential dwelling facilities, 30 percent had two or more such basic deficiencies, while 15 percent had three or more" (PRA, 1958). Because of such deficiencies as "serious deterioration, serious overcrowding, lack of sanitary facilities, and serious inadequacies in lighting and ventilation" (PRA, 1958), a large proportion of housing units in the neighborhood were condemned under the federal urban renewal program. Homes were subsequently cleared and their residents relocated.

"Various forms of local assistance were provided to Fain and his partners in the development's construction, including subsidized mortgages and mortgage insurance under the section 221 (d) (3) and Section 220 programs of the National Housing Act" (Milito, 1990).

The project was, therefore, built in two phases, with each of these in turn divided into two "sub-developments". Both were completed by 1968. Each phase involved the construction of some units being built under the provisions of the Section 221 (d) (3) mortgage and some with the section 220 . The units built with the section 221 (d) (3) mortgage would be set aside for lower income tenants, while the remaining units built with the section 220 mortgage were rented to moderate and market income tenants (Milito, 1990). It was this combination of mortgages that made the mixed income of residents possible. 
Irving Fain's goal was successfully attained and University Heights remained an intact racially mixed neighborhood for many years after Fain's death in 1970.

However, several occurrences in the mid-1980s caused significant changes at University Heights. A dramatic increase in real estate values began, causing home prices to increase approximately 25 percent per year, "resulting in significant increases for tenants across the board" (Milito, 1990). In addition, affordable rental units were further pressured by the expansion of the condominium market and subsequent conversion of many rental complexes into condominiums.

Additionally, Irving Fain's heirs decided to sell the development in 1985, simultaneous to the 20-year "option-tosell" milestone of the first phase of the development. Upon assuming ownership, the new owners, University Heights Associates (UHA), proceeded to prepay the Section 221 (d) (3) mortgage which covered 48 of the 150 units that comprised the first phase of the development (Milito, 1990). As a result, about 35 families were displaced, according to ATUH President Harry Platt. "'And there was no limit to how much the rent could be increased' Platt said. Some of us started to worry that a wonderful way of life that we'd never known before, a way that led us into friendships, and relationships beyond our experience, was slipping away" (Dykas, 1990). In addition, UHA announced that it would soon prepay the remaining section 
221 (d) (3) mortgages, which covered the remaining 102 affordable units, as soon as possible.

\section{The Emergence of ATUH}

"In response to this threat to our community, a group of tenants formed the Association of Tenants of University Heights," recalls Platt. "The board members of ATUH were a group of ordinary tenants with no particular real estate background or expertise. The group was a cross-section of the University Heights community and included a salesman, a printer, broadcaster, several clerical workers, and a few retired persons. But our lack of real estate expertise was matched by our desire to preserve our community and our willingness to work together to reach that goal" (Platt). Although many of these tenants resided in market rate apartments and were largely unaffected by the prepayments, they were outraged that their community's stability had been eroded by the new owners and their apparent goal of transforming the entire development into market rate apartments.

The core group that would eventually form ATUH's board of directors had begun meeting regularly by this time and had begun soliciting support from the tenants-at-large. Tenant association fees of $\$ 10$ were collected and the board members began to formulate strategies to prevent the prepayment of the mortgages on the second phase units. The Association's long- 
term goal, however, was the preservation of University Heights' community.

\section{The Need for Technical Assistance is Recognized}

Platt, as a salesman, had formidable experience in negotiation and was supported by an ever-growing and determined group. Even he realized, however, that the skills needed to bring their goals into fruition did not exist among them. Outside expertise was needed to translate their determination into an effective coalition. This, he reasoned, could only be accomplished by a united and cohesive tenant organization. Despite the impressive group assembled, experience in maximizing tenant support was needed. It was then that ATUH made contact with Asata Tigrai of Project Basic, a tenant organizing group that was instrumental in expanding ATUH's support base.

Tigrai was able to Provide advice and assistance to ATUH, guiding them in the publication and distribution of leaflets and coordinating of tenant meetings. When ATUH's first atlarge meeting brought 35 people--a 10 percent turnout--Platt was disappointed. "This kind of turnout was encouraging," Platt was told by Tigrai. A large and cohesive show of unity took time, and a 10 percent was more than adequate for a first attempt (Platt, 1991). 


\section{Legal Assistance}

In 1986, ATUH, at Tigrai's urging, made contact with Rhode Island Legal Services (RILS) and were accepted as a client. ATUH had begun pursuing their goal by another angle-the legality of prepayment if lower income or minority groups are affected. With the assistance of Michael Milito of RILS, the Association had filed a federal court lawsuit challenging the proposed prepayment of the phase two mortgage, primarily on the grounds that prepayment would cause injury to those subsequently displaced and was in violation of the Fair Housing Act of 1968. As a result, ATUH was successful in postponing the scheduled prepayment in June 1987 until after the case could be heard.

During this time, UHA had decided to sell University Heights and were in the process of seeking out prospective buyers while the lawsuit was pending. Their efforts to find a buyer were hampered, however, because of the lawsuit. ATUH's case against UHA had such an influence on prospective buyers that the buyers themselves were approaching ATUH to discuss "terms under which ATUH would be willing to dismiss the lawsuit" (Milito, 1990).

Although ATUH had initially focused its attention on preventing the prepayment of the second phase section 221 mortgage, they found that they could not come to any agreement with any prospective buyers on the affected 102 units. It became apparent to ATUH that the only way to ensure the 
achievement of their long-term goal was the purchase of the development themselves. They therefore decided to make an offer. It was at this point that another dimension of technical support was needed--real estate and development expertise.

\section{Community Builders}

By 1987, ATUH had recognized that they were greatly in need of assistance in putting together a workable financial plan to acquire University Heights. They faced significant constraints, however, in that they had limited funds and could not afford the services of a development consultant.

This changed, however, when ATUH made contact with The Community Builders, a non-profit real estate development consultant specializing in the provision of real estate technical assistance to community-based organizations. During this time, Milito was hired by The Community Builders as Project Developer for this and other developments in the region. The Community Builders worked with ATUH under the agreement that the Association would repay fees upon their acquisition of University Heights. With their services secured, ATUH began the formulation of a proposal and the development of a financing plan for the development's acqusition. By November of 1987, the Association was able to enter into a Purchase and Sale Agreement with UHA for the acquisition of University Heights (Milito, 1990). 


\section{Financing Plans are Initiated}

During the next two years, ATUH endured the arduous task of obtaining and compiling the necesary approvals from HUD and coordinating the complex links that made up the project's financing plan. Two components were particularly difficult to coordinate: the Approval for a Plan of Action and the Application for a Transfer of Physical Assets (TPA) .

The Plan of Action was difficult largely because of HUD's inexperience with at-risk developments. As result, recalls Michael Milito, "the process was far from streamlined" (Milito, 1990) and the HUD central office changed policies governing income eligibility a number of times during this period. For example, there were no clear guidelines set for Section 8 subsidies to tenants earning between 50 and 80 percent of the area median.

"The TPA also presented problems", recalls Milito. "ATUH was originally advised not to submit an application for TPA until a decision had been reached on its Plan of Action, on the theory that ATUH would not be able to identify its financing plan in the TPA until it knew what HUD's participation would be. This proved to be bad advice as ATUH subsequently was told that the Plan of Action could not be approved until the TPA was approved first. The bottom line is that it took HUD nearly 15 months to approve ATUH's Plan of Action" (Milito, 1990). 


\section{State and Local Government Involvement Begins}

While ATUH's financing plans were being formulated with HUD, Harry Platt began approaching state and local leaders. "It was a working plan, good enough to go to the owners with," recalls platt "but we needed a deposit to get a six-month period to show what we could do, to show that we could pull it off, raise the money" (Dykas, 1990).

The Community Builders persuaded Mayor Joseph Paolino of Providence to give ATUH $\$ 50,000$ as a deposit to UHA, who were in turn persuaded to extend their sale deadline from six months to 18 months.

Among the other government agencies approached by ATUH were Rhode Island Housing, The Governor's Office of Housing, Energy and Intergovernmental Relations (GOHEIR), and the Providence Housing Authority (PHA). "At first they laughed at us, sort of, but they listened, and slowly it began to happen," said Platt of ATUH's efforts to obtain financing commitments. "Along the way, Mayor Paolino kicked in another $\$ 1$ million 'to show city interest in the project' and Rhode Island Housing added another $\$ 750,000$ from its targeted loan fund, and finally, in March, it all came together, RIHMFC approved the project--\$22.5 million--and on october 17,1990 it happened, the sale was consumated" (Dykas, 1990). Thus the largest mortgage ever supplied by RIH, combined with assistance from The Community Builders, Project Basic, RILS, GOHEIR, HUD, and the City of Providence, at last made ATUH the 
CHAPTER THREE

SUBSIDIZED RENTAL HOUSING IN RHODE ISLAND

\begin{abstract}
With the series of events undergone by ATUH in mind, it is important to remember that those units affected by prepayment at University Heights makes up less than two percent of at-risk subsidized units in Rhode Island. This chapter will put University Heights and the efforts of ATUH into context by providing an overview of the state's subsidized rental units and the significance of the threat they face.

The programs relevant to the state's rental housing stock will be reviewed, namely those under section 221 (d) (3), Section 236, and section 8 jurisdiction. In addition, an inventory of those rental units actually in jeopardy will be provided. This inventory will include those units among the above programs considered "very likely to prepay" and "likely to prepay" as categorized by Rhode Island Housing (RIHMFC, 1988).
\end{abstract}

Section 221 (d) (3)

Section 221 (d) (3) was originally created to assist rental housing affordability and production. Under this program, HUD was to pay a portion of mortgage interest payments to allow owners to reduce the amount of rent charged to tenants. In addition, HUD was allowed to provide below- 
owners of University Heights.

\section{Ownership of University Heights}

The development is now "owned by the...Association, a nonprofit corporation organized under the laws of the State of Rhode Island. ATUH has been determined to be exempt from federal taxation under Section 501 (c) (3) of the Internal Revenue Code" (Milito, 1990). It is a membership-based corporation in which all persons residing within the development are able to join, with annual membership dues set at $\$ 10$ per unit. As of April 11, 1990, the board consists of

12 members. Only members of the Association are eligible to become directors, and directors are elected at annual meetings of the Corporation in the March of each year (Milito, 1990). 
market interest rates to owners in return for an agreement to set aside a number of units for low-income tenants (chung, $1988)$.

"This program was criticized", according to Chung," because HUD could only lower the interest rate to one percent. Thus, the lowest income groups were priced out of the market. In addition, the program was not popular with the federal government because the entire amount to be loaned was included in the yearly budget" and caused considerable complications. As a result, the section 236 subsidy program of the Housing Act of 1968 was created to supersede this program (chung, 1988).

\section{Section 236}

Like Section 221, the interest rate charged on a section 236 project can be as little as one percent. It differs, however, in that it pays the subsidy to the project owner annually as opposed to buying the mortgage in its entirety at the outset. Thus, at its outset in the late 1960s, the program was initiated to create incentives for developers to construct and manage low and moderate-income housing. In this way, "mortgage interest subsidies under a host of programs and rent supplements were provided either individually or in combination to make it profitable for private intrepreneurs to produce decent housing at below-market rents". According to Chung's analysis: "Overall, in the 1960 s federal housing 
assistance was designed primarily to augment the supply of housing available to low and moderate income families" (1988).

This program was evaluated by the Nixon Administration in the early 1970s, and as a result, a moratorium was imposed. A subsequent 1973 report revealed that the cost of many units subsidized by the program were higher than their actual value. In addition, it was found that an insufficiently low number of household were being served by the program and that a substantial number of projects assisted under the program were defaulting on their loans. As a result, the moratorium imposed on the program was never lifted.

The following year, the Housing and Community Development Act of 1974 was enacted. This Act redefined the role that the federal government would play in housing, urban development and many other forms of assistance. It contained a new and flexible approach to housing assistance: the section 8 subsidy program.

\section{Section 8}

This program is comprised of two sub-programs: Existing Housing and New Construction/Substantial Rehabilitation programs. Under the Existing Housing Program, tenant eligibility is based on income--those earning less than 80 percent of the local area median income are eligible. The tenant pays 30 percent of his or her income toward rent, and the difference between that amount and what is deemed the 
"fair market rent" is made up by HUD.

Under the terms of the New Construction/Substantial Rehabilitation Program, a 20 to 30-year agreement is made by HUD at the time of a development's construction "to pay the difference between the full rent of the units developed and a fixed share of the tenant's incomes for those units occupied by program participants" (Chung, 1988). This program differs from the Existing Housing Program in two fundamental ways. First, the New Construction/Substantial Rehabilitation Program spurs the production of new low-income units, while the existing housing program does not. In addition, rental assistance for the tenant under the New Construction/Substantial Rehabilitation Program is limited to the actual constructed unit, while under the existing housing program, rental assistance is more flexible and moves with the tenant. In other words, income-eligible tenants have choice as to where they would like to live and may apply their Section 8 contract to any number of rental units. Under the first program, however, the subsidy is "anchored" to the constructed unit.

\section{Changes in Housing Policy Under the Reagan Administration}

Housing policy underwent additional, more radical, alterations during the Reagan years. Between 1981 and 1987, the bugget for HUD's subsidized housing program was cut from $\$ 30.1$ billion in fiscal year 1981 to $\$ 10.7$ billion in fiscal 
year 1987. This translates to a reduction in the number of new units to be covered by HUD funding from 204,000 in 1981 to 76,406 in 1987 (Chung, 1988).

Specifically, such programs as the New Construction / Substantial Rehabilitation Program were cut under the Housing and Urban Recovery Act of 1983. In addition, the Act established an experimental voucher-based program under which the amount of rental assistance is determined by the income of eligible participants minus the local fair market rent. Like the Existing Housing Program, this program does not perpetuate new construction. It differs, however, in that tenants are free to rent units above the fair market rate. Vouchers have five year terms of commitment, unlike the original section 8 programs, which have five year terms that are extendable to up to fifteen years.

The Housing Voucher program first yielded units in 1985, so 1985 and 1986 are made up entirely of voucher-based units.

Another notable change in housing policy that occurred during the Reagan years was an increase in the percentage of income that the tenant had to contribute toward rent. This proportion increased from 25 percent to 30 percent (Chung, 1988). Thus, rental housing policy has faced a considerable degree of change during this time. None of these changes have offered low and moderate-income tenants a better alternative or security of tenure. The challenge facing government at 
all levels is the creation of a balance between the contractual rights of rental property owners and the needs of low and moderate income tenants. This challenge, however, must also be shared by tenants. As it appears unlikely that federal government expenditure on subsidized housing will increase, tenants must explore their own options in providing themselves with security of tenure. The number of affected tenants is substantial, as indicated by Rhode Island Housing: 2,423 units in 19 developments in the "very likely to prepay" category and 2,505 units in 26 developments classified as "likely to prepay" (RIHMFC, 1988).

As ATUH President Harry Platt noted, the substantial number of tenants affected also has a positive side. If these tenants organized, reasons Platt, they could wield substantial political power. For example, University Heights comprises a significant proportion of District 6 of Providence. According to Platt, an average of 300 voters participated in recent elections. With 349 units, University Heights could easily impact the outcome of any election if it organized and chose to do so.

An inventory of the "very likely" and "likely to prepay" will now be provided to identify the scope of the problem on the local level.

Potential Impacts of Prepayment on Rhode Island

According to Chung, Providence would be hardest hit of 
all Rhode Island communities in the event of increased mortgage prepayment. For the state, the percentage of renteroccupied housing units as of 1988 is 41 percent, while the proportion in Providence is 56.2 percent (Chung, 1988).

As estimated by RIHMFC, over 650 units in Rhode Island are categorized as either likely or very likely to pay in 1991 alone. Until 1996, the furthest year projected by Rhode Island Housing, several hundred units per year are considered in serious jeopardy. 1994 is the peak year, with over one thousand units threatened by prepayment.

This proportion of affected tenants further underscores the importance of tenant organization. Provided with the example of ATUH, tenants must recognize the significance of eminent prepayment on the developments in which they reside and act accordingly. The basis for such action, as illustrated by the events of University Heights, can best be provided by the first of the six elements--strong leadership. The following chapter will discuss the leadership style of ATUH board members, particularly its president, Harry platt. An overview of their leadership will culminate in the identification of what actions can--and must--be replicated in order to achieve social ownership. 


\section{CHAPTER FOUR}

\section{STRONG IEADERSHIP}

This chapter will discuss the first element--strong leadership. Although the importance of these elements vary by organization, the leadership provided by ATUH was clearly one of the primary factors in the Association's success. The initiative and determination of Harry Platt and other ATUH board members had everything to do with the Association's success.

\section{Leadership in Tenant Organization: Why is it Important?}

Two primary differences between a CBO formed to build affordable housing and one formed in response to the threat of prepayment are obvious: the immediacy of the threat and the consequences of failure. Although the failure of a CBO with the goal of acquiring and developing affordable housing is unfortunate, the failure does not result in the displacement of low and moderate-income groups. When faced with mortgage prepayment, the tenants of a threatened housing development must act quickly and effectively. This is where leadership of the tenant organization comes into play.

In her 1984 publication, Urban Neighborhoods, Networks, and Families: New Forms for Old Values, Wireman identifies seven general conditions that must exist in fostering the development of "good participation". For the purposes of this 
study, these will also be assumed to be conditions necessary for a strong tenant association. What is immediately apparent is the fact that these conditions must all stem from one source--the leadership provided by an individual or core group who lead the tenant organization. These conditions are:

1. Provision of information on an ongoing basis and early in the decision-making process

2. Availability of trusted technical assistance as an aid to understanding complicated or technical programs

3. Regular meetings with decision makers during their deliberations

4. An organization that is perceived by both city officials and neighborhood residents as being representative of the area

5. An acknowledged right to participate and a clear commitment by bureaucrats to the process of citizen participation

6. Ability to achieve at least some goals on a fairly consistent basis

7. Sufficient ongoing stable financial support to relieve a group from spending most of its energies on fund raising, often on a crisis basis. (Wireman, 1984 ).

These conditions highlight precisely what is expected of tenant association leadership and what responsibilities they are to assume. Only the fifth condition, commitment on the part of bureaucracy, is inapplicable to tenant associations. As little can be done by associations to change government bureaucracy's perception of them, they must work around this condition and concentrate on the third condition--regular 
meetings with decision makers--for it is their perception (and financial support) that really counts. As a result, this will not be discussed. The sixth condition, the ability to achieve goals on a regular basis, does not have direct parallels either. By no means, however, does this indicate that the consistent achievement of goals is not essential. In fact, it will be argued that incorporating this strategy can be greatly beneficial to tenant associations--especially as a tool of generating support and boosting morale. This is especially so of CBOs in search of capital.

\section{Application of Wireman's Conditions to the Case Study}

1. Dissemination of Information

The leader's role as provider of information for a tenant association can be described as two-dimensional. Both lines of communication within the Association, well as lines to outside players (technical supporters, political leaders, etc.) must be managed by leaders.

A. Managing Intra-group Communications

With regard to the provision of information, leadership is the focal point of the communication network that supports the CBO. In terms of intra-group or intra-neighborhood communication lines, leadership in the form of a board or an individual clarifies the CBO's goals and objectives. This is mainly so because some form of hierarchy or chain of command is necessary in maintaining cohesion in the organization. 
One of the first lessons that Harry platt learned in initiating an active tenants' assocation was the importance of a clear focus and coordination offered by a core group. From his association with Asata Tigrai of Project Basic, he learned the fundamentals of tenant organization. These fundamentals included the generation of support for the achievement of ATUH's goals through meetings, the distribution of flyers, and gaining acceptance and legitimacy from political leaders, lending institutions, and other potential allies. These activities simply cannot be achieved without an agenda and the focus provided by leadership.

\section{B. Managing Communications With Outside Players}

In terms of the $\mathrm{CBO}^{\prime} \mathrm{s}$ communication lines with outside organizations and agencies, again the primary responsibility lies with the Association's leaders. As these leaders must negotiate and persuade political leaders, lending institutions, and public agencies, certain experience, skills, or personal attributes are useful. In the case of University Heights, this is certainly the case. As wireman notes: "The difference in tactics selected by different [tenant leaders] may reflect philosophical positions, but is also related to the socio-economic position of the group. Middle-class persons who interact regularly with politicians and city officials at business meetings or social gatherings or whose contributions are politically important do not have to resort to sitting in at the mayor's office in order to have their 
concerns heard" (Wireman, 1984). No members of ATUH interact regularly with politicians, nor are they by any means uniformly middle-class. "The members of ATUH are ordinary people," asserts Platt, "not financial wizards or developer types. We have no wall street merger ability, just a willingness to work hard and stay focused on reaching our goal" (Platt, 1990). In the case of University Heights, therefore, the mixed-income nature of the development ensured that middle-income residents would be included in ATUH's makeup. This may have been helpful in avoiding the class, ethnic, or racial conflicts that have characterized numerous negotiations between tenant groups and government in the past (Wireman, 1984).

Examples of these conflicts include rent strikes by the East Side Tenants Union (ESTU), made up primarily of lowincome immigrants, and their dispute with New York City Mayor Fiorello LaGuardia; as well as the tenants of Boston's West Side and their clash with proponents of Urban Renewal in the late $1950 \mathrm{~s}$.

The latter example has particular relevance to University Heights. Unfortunately, it exemplifies the wrong approach by tenant association leaders and the consequences of poor leadership. This tenant's association, as chronicled by Herbert Gans in The Urban Villagers was formed by the largely Italian-American residents of the neighborhood who were forced from their homes by the development of luxury high rise 
apartments (Gans, 1962). Gans' illustration of a lack of leadership among the tenants of the west End and its unfortunate consequences only underscore the need for established lines of communications. As these lines are best formed by leaders and an established hierarchy, tenant groups should be aware of these implications.

\section{Availability of Technical Assistance}

The link between a tenant association's leadership and the technical assistance provided to the group is every bit as vital as the lines of communication that serve them. For without some form of representation, working with such technical support personnel as lawyers, developers, real estate agents, and lenders would be chaotic and ineffective. It is therefore necessary that an association consolidate a knowledge of its goals and resources in several capable individuals who can work one-on-one with technical support staff.

To contrast once again with Gans' case study of Boston's West End, ATUH achieved their goals in one sense because of indifference on the part of a significant proportion of University Heights. This allowed ATUH an autonomy that was instrumental in their success. As Gans notes of the conditions that must be in place for leadership to be effective :

"The peer group must, above all, give life to the 
individual, and cooperative action directed toward a common end detracts too much from this central purpose. Moreover, West Enders are reluctant to place themselves in a leader-follower, officermember relationship, which would detract from the individuating function of the group and would also require members to assume a subordinate, if not dependent, role towards the leader. Consequently, only a highly charismatic leader seems to be able to attract followers and retain their loyalty for any length of time" (Gans, 1962).

This situation is completely converse to the experiences of ATUH, who were able to function free of interference from other University Heights tenants. This is largely because of the fact that not all tenants (less than one third) were to be negatively affected by prepayment. As a result, the number of "chiefs" was mitigated to a minimum number, one conducive to productivity.

The reigns were, therefore, taken by ATUH without the tumult and panic that characterized the west Enders' attempts to mobilize. "In fact," wrote Gans, "one of the reasons for the inability of the Save the West End Committee to function was the desire of most of the participants to be leaders and their unwillingness to carry out the routine tasks required. The familiar complaint of community organizations everywhere-'too many Chiefs and no Indians'--is perhaps nowhere more true than among people like the west Enders" (Gans, 1962).

In short, a conflict for leadership never occurred among the tenants of University Heights, nor did it occur inclusively among the board members of ATUH. This lack of 
conflict greatly aided ATUH in its dealings with its technical supporters, namely Project Basic, RILS, and The Community Builders.

\section{Regular Meetings With Decision Makers}

Many of the principles discussed under the previous section also apply to the importance of leadership when meeting and negotiating with political leaders. Just as an organization's leadership must represent their goals and wishes when dealing with technical support staff, so must it represent them when the association deals with political leaders. "I had been to see [Providence] Mayor Paolino and [former Rhode Island] Governor Diprete," recalls Harry Platt, "and I tried to interest them in rent controls, but as soon as I mentioned that, their eyes would glaze over. So I was trying to beef up my arguments with votes represented by members of a Tenant's Association" (Dykas, 1990). As a result, Platt went through the process of organizing and incorporating ATUH. In this way, he was able to assert ATUH's position as a political power in the city by reminding local politicians of the proportion of voters University Heights represented.

This exemplifies the importance of singular leadership: Harry Platt met with Paolino and DiPrete and determined that University Heights would have to prove to politicians that a failure to respond to the needs of University Heights tenants 
would somehow bring undesireable repercussions. Large groups cannot negotiate effectively with political leaders. Harry Platt was able to bring the collective desires of ATUH to meetings with the Mayor and Governor, and then make key decisions for the group. This further underscores how essential representation is in proving unity and legitimacy to the federal, state and municipal government. This is particularly noteworthy in light of the fact that, "along the way, Mayor Paolino kicked in another $\$ 1$ million 'to show city interest in the project" (Dykas, 1990).

4. Perception by City Officials and Residents that the organization is Representative of the Area

Yet another responsibility of tenant association leadership is forming a group with goals and policies that truly represents the interests of the people who reside there. wireman's condition, therefore, should go beyond calling for the "perception" of proper representation and mandate actual representation. In the case of $\mathrm{ATUH}$, the board members were "an ordinary group of tenants with no particular real estate background or expertise. The group was a cross-section of the University Heights community and included a salesman, a printer, broadcaster, several clerical workers and a few retired persons" (Platt, 1990). By forming a group of such diverse backgrounds, ATUH was able to prove to political leaders, as well as lenders, that the Association did represent the interests of all University Heights tenants. As 
a result, they were able to get what they wanted. Thus, ATUH recognized that only by creating an association open to all residents were they to be viewed as legitimate in the eyes of potential financial supporters.

6. Ability to Achieve at least Some Goals on a Fairly Consistent Basis

A tenant association's leadership must, according to Wireman, be able to lead the group in the achievement of at least some goals on a fairly consistent basis. She reasons, rightfully so, that the association would become disheartened if their efforts appeared pointless and would give up. The leadership must recognize this and plan accordingly. For instance, smaller-scale, more manageable objectives should be arranged in a timeline that is realistic, yet incorporates moderate objectives that are rewarding when achieved.

No direct parallels, in fact, exist between this condition and the case study. However, as discussed earlier, the setting of achievable goals can prove invaluable to associations with flagging morale and a need to see that their efforts are not in vain. If tenants who have not yet joined an association see it making strides, they may feel compelled to join. This would probobly not be the case if a CBO had obscure goals with no immediate prospects of achieving them. In sum, leadership must provide a carrot and stick with which to move the organization forward. 
7. Sufficient, Ongoing Financial Support

The role of leadership again arises in the attainment of the final condition--stable financial support. Examples of this include small tokens of financial support, such as ATUH's collection of a $\$ 10$ per tenant monthly charge, as well as the "landing" of a $\$ 22.5$ million Rhode Island Housing mortgage. In addition, the Association's leadership successfully solicited the assistance of Project Basic,RILS, and The Community Builders with "special arrangements, as in the case of the Community Builders, which entailed a payment scheme similar to that of a "pay us only if you win" lawyer. Under this arrangement, ATUH was able to retain the services of The Community Builders throughout their formation and arranged to pay fees due upon acquiring University Heights.

Conclusions

This application of Peggy Wireman's prerequisite conditions for the development of "good participation" has been undertaken to highlight the importance of leadership in attaining tenant ownership. The many facets of responsibility that are entrusted with a tenant association leader for leaders) have been elaborated upon to provide the foundation upon which a CBO can form.

Such responsibilities as the desemination of information, frequent contact with technical support staff, negotiations with political leaders, inclusion of a cross-section of 
tenants, the consistent achievement of goals, and sufficient management of fundraising activities are all part of the frustrating yet rewarding aspects of being a tenant organization leader. As was illustrated in the ill-fated organization of Boston's West End residents described in The Urban Villagers, a lack of leadership produces the inevitable undesireable results. The example provided by Harry Platt, Marge Day and Bessie Jones and other ATUH board members is one of a favorable outcome based on their "drive, determination and organization" (Platt, 1990).

Equally important to leadership is the degree of cohesion achieved by an organization. The following chapter will discuss this issue. 


\section{CHAPTER EIVE}

\section{TENANT COHESION}

Like leadership, the degree of cohesion demonstrated by a tenant organization is characterized by two primary factors; first, both form the basis of the organization's success; and second, they are the only two factors that are directly influenced and controlled by the tenants themselves.

With regard to the first factor as it applies to University Heights, there is some evidence of a strong relationship between tenant cohesion and the tenant organization's success. This is largely because there would be no point in efforts to purchase the development without some degree of unity displayed by its tenants. Secondly, tenant cohesion and leadership, unlike technical support, financing, and government commitment, must be fostered within the resident population of the development. While ATUH obviously had a strong voice in the type or degree of technical support supplied to them, cohesion and leadership must be inherent in the tenants' collective character.

This chapter will provide an overview and analysis of cohesion as it influenced--and continues to influence--the dynamics of tenant empowerment as displayed by ATUH. It will be divided into three parts, each of which cover some of the fundamental dimensions of tenant cohesion.

The first part will describe centripetal forces that 
determine the degree of cohesion ultimately achieved by a tenant group. They include conditions identified by Edelstein and Wandersman (1987) in their framework as sparking cohesion, which will be presented to outline some circumstances that facilitate tenant cohesion. This framework will describe how external threats galvanize tenant or community relations.

This will be contrasted to an example of tenant cohesion without immediate threat to illustrate that tenant organization need not be sparked by encroachment from outside forces (i.e. prepayment). This case study will describe the efforts of tenants in Monkwick, Colchester, a British government-owned housing development, highlighting their successful organization and acquisition endeavors.

Incorporating the first two factors, the third part will examine the essential collective role that tenants play in providing support to the organization's leadership. Whatever the causes and characteristics of its formation, a tenant organization's main body plays a vital collective role in its success. As Wireman's seven criterion served as the framework for describing the tasks of tenant leadership, the "unwritten" functions assigned to tenants will be analyzed using a framework provided by Edelstein and wandersman in their study of Legler, New Jersey residents and their collective response to the contamination of their drinking water.

These functions differ from the specified roles of tenant 
leadership in that they are more broad and undefined. They are less tasks or jobs than vague "conditions" that must exist in the collective character of a development's tenants. These functions, as described by Edelstein and Wandersman, are:

\section{Social Support \\ 2. Sources of Information \\ 3. Sources of Power}

Other tenant and neighborhood groups have historically faced such varying threats as urban renewal in Boston (Gans, 1962 ) and New York City (Davies, 1966) or "neighborhood rehabilitation" in Israel (Churchman, 1984), rent increases in Berkeley (Clavel, 1986) and New York City (Spencer, 1981), and contamination of drinking water, as was described in the article that provided the above framework. Each of these support Edelstein and Wandersman's findings that the above functions have a significant degree of influence on the success (or lack thereof) of a tenant organization.

An overview of these dimensions of tenant cohesion is intended to complement the functions of tenant leadership described in the previous chapter. Before a discussion of tenant cohesion, however, it is important that certain terms used in this chapter be clarified. Research for this study raised such terms as "community organization", "neighborhood organization", "tenant organization", and "public participation"--all of which were applicable, to a certain extent, to University Heights. It became apparent, however, that the situations described by these terms varied greatly in 
scope. For instance, tenant organization as described by Spencer (1981) entailed a complex network of small, fragmented tenant groups from throughout New York City; while community organization as described by Edelstein and Wandersman referred to a concentrated section of a rural area situated above a contaminated groundwater aquifer.

What was necessary in drawing appropriate comparisons between such case studies and University Heights was the standardization of the above arbitrary terms. For instance, the similar characteristics are displayed by tenant organizations on the neighborhood, city, or state or national scale. If these characteristics are standardized (i.e. compared to scale with ATUH), then the case studies can be effectively compared.

\section{A Clarification of Terms}

A large number of studies have documented the importance of the role that public participation and neighborhood cohesion (e.g. Clavel, 1986; Churchman, 1987) have played in bringing about effective change in communities of varying sizes and makeup. In discussing tenant cohesion in the case of University Heights, however, it is important to begin by clarifying definitions.

The terms "neighborhood cohesion" and "tenant cohesion" will be used interchangeably, as the development replaced a neighborhood--Lippitt Hill--and assumed the basic functions 
that this previous neighborhood served. These functions include the provision of a place to rear children, housing, a delivery point for a variety of administrative and political services, an economic base, and social relationships (Wireman, 1984). The entire development, therefore, is considered a "neighborhood" because of its uniqueness from surrounding neighborhoods. Tucked between the Mount Hope neighborhood to the north, Hope High School to the east, College Hill to the south, and Randall Square to the west, University Heights is largely insular in design and location. The placement of its buildings form pleasant green courtyards that are conducive to interaction. This, combined with such physical boundaries as the adjoining shopping center, form University Heights' identity as a neighborhood.

Additional clarification is necessary in defining such terms as "public participation", as well as determining the difference between "neighborhood organization" and "community organization". As the actions of ATUH display many of the characteristics of organization described by Edelstein and Wandersman (1987); Churchman (1987); Gans (1962); Davies (1966); and Boyte (1981); each of these discuss organization on different scopes. For instance, Boyte, in his discussion of community organization during the 1970s, touches upon many of the same principles employed by ATUH. In the article, he outlines the tactics used by veteran organizer Saul Alinsky. These include the importance of "building indigenous 
leadership" upon pre-existing frameworks (such as ATUH's use of the nearby Camp street Baptist Church, where tenant/board meetings are held, as a base for support) and "organizing people for power", which Boyte described as motivating people by appealing to "their own directly perceived self-interest on concrete issues". This is apparent in ATUH's success in forming alliances "across a broad range of opinion", i.e. the ability to appeal to all spectrums of University Heights' racial, cultural, ethnic and class makeup.

"Community organization", therefore, often takes place on a citywide or even regional scale, uniting people with same interests. "Neighborhood organization" (or, in this case, "tenant organization") refers to shared goals for a defined neighborhood and efforts to achieve those goals collectively. While many of the tactics and principles that apply to community organization also apply to organization on the neighborhood level, it is important to distinguish the potential for wider scope in community organization.

The other principal difference between the two is the wider range of issues that are taken up by community organizations. Neighborhood organizations form in response to issues that have an impact on neighborhoods as geographic locations. ATUH, for instance, formed because of shared concern by University Heights tenants that their "way of Iife would be forever changed" (Platt, 1990). Therefore, such issues as rent increases, environmental threats (as in the 
Edelstein and Wandersman article, which will be discussed later in this chapter), and urban renewal (as in the case studies provided by Davies and Gans, also to be discussed), all have a bonding effect which facilitate neighborhood cohesion. Community organization, on the other hand, presumes a much wider scope in terms of a.) issues addressed: community organizations have been formed to address any issue from undesired development (with effects on the neighborhood level) to local tax rates (with effects on a wider scale); and b.) spatial distribution of the organization's supporters. In other words, location of residence may not be as important a consideration in the mobilizing of support for some community organizations.

The last clarification necessary is the definition of "public participation". This is because much of the literature cited in this study (e.g. Clavel, 1986) include discussions of public or "community participation" in terms of progressive governments that encourage such participation. Thus, while some of the principles of public or "mass" participation are applicable to ATUH, some degree of caution was necessary with the use of terminology. This caution was necessary for precisely the same reason the difference between "neighborhood" and "community organization" had to be clarified--a problem of scope. This is best illustrated in the difficulty finding appropriate literature under "public participation" during a literature review for this study. It 
became apparent that an incredibly wide variety of scenarios were included under this heading. Such participation could include tenant participation, but could also include the "mass participation" that characterized movements of much larger scale. Examples of this include the cities of Hartford, Cleveland, and Santa Monica and their inclusion of mass citizen participation as public policy (Clavel, 1986).

\section{Centripetal Forces That Determine the Extent of Tenant Cohesion}

When a group of tenants are confronted by some form of threat, they do something they might not otherwise do--they form an alliance. As Platt will attest, "we only organized because we were so angry with [the previous owners of University Heights]" (Platt, 1990). Although some superficial signs of friendship based on proximity often exist, as described by Fischer (Wireman,1987), tenants or neighbors are often not drawn together until faced by a shared threat.

The dynamics of this phenomenon are best illustrated by Edelstein and Wandersman's overview of community response to toxic contamination in the case of Legler. "As the result of the announcement of toxic exposure, the affected community is thrown into turbulence. In their attempts to cope with this turbulence, residents of affected areas turn naturally to key components of their social environments: a.) the 'social network' or existing group of friends or relatives who can 
normally be expected to offer assistance or support in the face of crisis; and b.) the 'institutional network' of government agencies that is believed to be responsible for citizens in need" (1983).

The following are elements of the framework which makes up Edelstein and Wandersman's study of community organization in Legler. These elements have been applied on a point-bypoint basis to University Heights and the formation of ATUH. As will be seen, some elements conform more than others. Overall, however, there are considerable similarities between the mobilization patterns of the residents of Legler and the tenants of University Heights.

ENVIRONMENTAL TURBULENCE IEGLER RESIDENTS
PREPAYMENT OF MORTGAGES UNIVERSITY HEIGHTS (ATUH)

Problem Characterized By:

\begin{tabular}{||l|l||}
\hline \hline 1. & \\
Disruption of everyday life \\
from anticipatory fears and \\
the complexities of the & $\begin{array}{l}\text { Displacement occurs, causing } \\
\text { panic among tenants. } \\
\text { situation. }\end{array}$ \\
& $\begin{array}{l}\text { Unfamiliarity with } \\
\text { complexities of mortgage } \\
\text { payments compounds this. }\end{array}$ \\
\hline
\end{tabular}




\begin{tabular}{|c|c|}
\hline \multirow{2}{*}{$\begin{array}{l}2 . \\
\text { Outsiders who are expected to } \\
\text { help may display contradictory } \\
\text { interests and actions }\end{array}$} & \\
\hline & $\begin{array}{l}\text { Platt's unsuccessful initial } \\
\text { attempts to convince City and } \\
\text { State leaders that rent } \\
\text { control was necessary. Their } \\
\text { response indicated a } \\
\text { reluctance to interfere with } \\
\text { this regard. This could be } \\
\text { interpreted as a conflict of } \\
\text { interest on the part of the } \\
\text { Mayor and Governor, both of } \\
\text { whom have close ties to real } \\
\text { estate and development. }\end{array}$ \\
\hline \multicolumn{2}{|l|}{3.} \\
\hline $\begin{array}{l}\text { An overall scarcity of } \\
\text { resources for solving the } \\
\text { problem faced by the affected } \\
\text { population. }\end{array}$ & $\begin{array}{l}\text { Before the forming of ATUH's } \\
\text { relationship with RILS, } \\
\text { Project Basic, RIHMFC and the } \\
\text { Community Builders, they had } \\
\text { no financial or technical } \\
\text { resources available to them. }\end{array}$ \\
\hline
\end{tabular}

\section{INITIAI COPING EFEORTS}

Seeking of assistance and support from:

(LEGLER)

(ATUH)

\begin{tabular}{||l|l||}
\hline 1. & \\
Social Networks & \\
"Support from one's & Tenants--especially longtime \\
social network is commonly & tenants utilized related \\
identified as essential to & networks (e.g. church) as a \\
attempts to cope with a & This for their organization. \\
variety of stressful & $\begin{array}{l}\text { This illustrated by close } \\
\text { situations." }\end{array}$ \\
& church.
\end{tabular}




\section{2.}

Institutional Networks People respond to environmental turbulence by seeking information and assistance from those having institutional roles commonly believed to give them expertise, power and responsibility to address the situation.
Exemplified by ATUH's efforts to seek help from community organizations, lenders, and City and state government-perceived as institutions that could provide them with the expertise and support necessary to preserve security of tenure at University Heights.

\section{COMMUNITY CHARACTERISTICS}

Made up of:

(LEGLER)

\begin{tabular}{||l|l||}
\hline $\begin{array}{l}\text { Environmental characteristics } \\
\text { desirability of the area }\end{array}$ & $\begin{array}{l}\text { Design features that encourage } \\
\text { human interaction (e.g. common } \\
\text { courtyards, high quality of } \\
\text { grounds and units are all } \\
\text { potential contributors to } \\
\text { tenant cohesion. }\end{array}$ \\
\hline $\begin{array}{l}\text { Ecological characteristics } \\
\text { geographic factors, size, } \\
\text { boundaries }\end{array}$ & $\begin{array}{l}\text { The insular design of } \\
\text { University Heights (e.g. all } \\
\text { units facing common } \\
\text { courtyard), isolation from } \\
\text { other neighborhoods (from } \\
\text { barriers such as wide roads, } \\
\text { fences may also contribute to } \\
\text { tenant. }\end{array}$ \\
\hline
\end{tabular}




\begin{tabular}{|c|c|}
\hline $\begin{array}{l}\text { Sense of Community } \\
\text { "Sarason (1974) suggested that } \\
\text { the ingredients of sense of } \\
\text { community are: "the perception } \\
\text { of similarity to others, an } \\
\text { acknowledged interdependence } \\
\text { with others, a willingness to } \\
\text { maintain this interdependence } \\
\text { by giving to or doing for } \\
\text { others what one expects from } \\
\text { them, the feeling that one is } \\
\text { part of a larger } \\
\text { dependable and stable } \\
\text { structure" (p. I57). }\end{array}$ & $\begin{array}{l}\text { Interviews with Platt and } \\
\text { Hebert (1991) indicated an } \\
\text { interdependence between } \\
\text { tenants (such as cooperation } \\
\text { with regard to security at the } \\
\text { development), satisfaction } \\
\text { with the degree of integration } \\
\text { achieved (Platt, 1990, 1991) } \\
\text { and that tenure of stability } \\
\text { at the development was of } \\
\text { primary importance. }\end{array}$ \\
\hline $\begin{array}{l}\text { Neighboring and Formal } \\
\text { Organizations } \\
\text { "After [the residents of } \\
\text { Legler] were notified of the } \\
\text { contamination, neighborhood } \\
\text { communication became an } \\
\text { important element in the } \\
\text { residents, coping. }\end{array}$ & $\begin{array}{l}\text { As discussed earlier, } \\
\text { centripetal forces, such as } \\
\text { the threat of tenure security } \\
\text { are an important factor in an } \\
\text { organization's formation. }\end{array}$ \\
\hline
\end{tabular}


INDIVIDUAL DIEEERENCES

(LEGLER)

(ATUH)

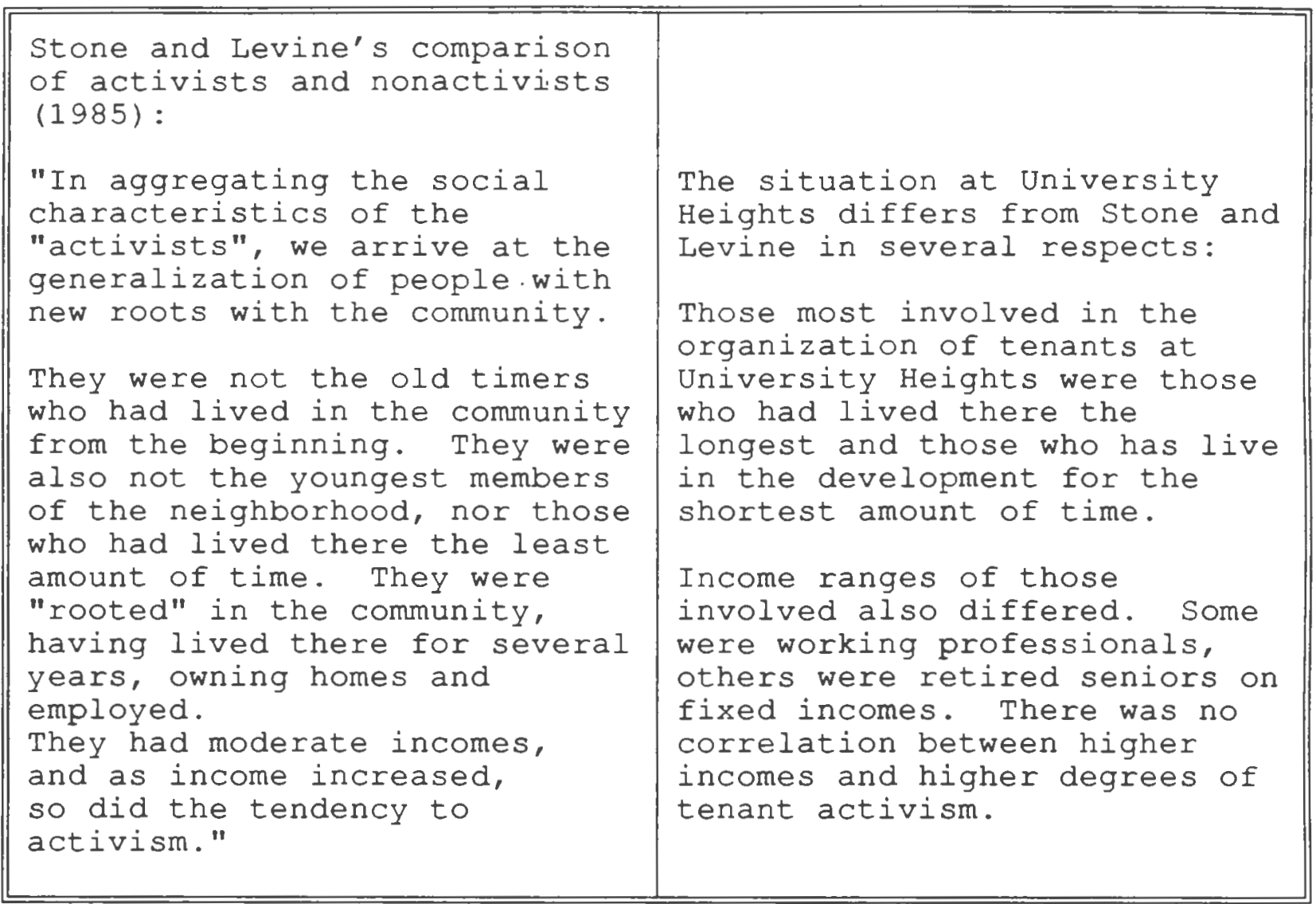


LEADERSHIP AND ORGANIZATION STRUCTURE

\begin{tabular}{|c|c|}
\hline $\begin{array}{l}\text { Orqanizational Structure } \\
\text { van Eijndhoven and Nieuwdorp's } \\
\text { (1985) findings that community } \\
\text { organizations varied in their } \\
\text { structure from highly } \\
\text { centralized and hierarchical } \\
\text { to consensual decentralized } \\
\text { structure. } \\
\text { Eg., Love canal, run } \\
\text { principally by a core of key } \\
\text { members yet frequent broad } \\
\text { participatory action } \\
\text { undertaken by affected } \\
\text { residents. } \\
\text { Leaders and Leadership } \\
\text { Eg., Legler, in which its } \\
\text { Concerned Citizen's Committee } \\
\text { formed around a core of } \\
\text { local activists. } \\
\text { Edelstein's (1982) findings } \\
\text { that the majority of work } \\
\text { in community organization } \\
\text { in Legler was undertaken by } \\
\text { a few key people, namely } \\
\text { the executive board. Most } \\
\text { other residents attended } \\
\text { meetings, but did little } \\
\text { else. }\end{array}$ & $\begin{array}{l}\text { Tenant organization at } \\
\text { University Heights conformed } \\
\text { to the former structure } \\
\text { described by van Eijnhoven and } \\
\text { Nieuwdorp. The tenant body of } \\
\text { University Heights ranged from } \\
\text { a small core of dedicated } \\
\text { tenants to a substantial group } \\
\text { who had little or no } \\
\text { involvement with ATuH. }\end{array}$ \\
\hline
\end{tabular}

(Adapted from: Edelstein and Wandersman, 1983)

\section{"Planned" Organization In Britain: Tenant Acquisition without the Threat of Prepayment}

While Edelstein and Wandersman's findings indicate that circumstances dictate a development's potential for tenant 
organization, an alternative is offered by Colin ward (1974) in his study of tenant purchases of government-owned subsidized housing in Britain.

In his argument for the transfer of municipal housing from local county councils to tenants, ward (1974) claims that the tax structure and housing policy of Britain in the late 1960 s and early 1970 s put home renters at a considerable disadvantage:

\begin{abstract}
"A friend of mine who bought a house less than 10 years ago sold it two years ago. with the untaxed profits he bought himself another house on mortgage, bought a new car, bought a small shop, and even collected rents from a flat above the shop. On top of that he got a better tax subsidy on his new mortgage. I don't know any council tenant who has been able to use his tenancy to get a higher subsidy, a new car, shop, and rent income from a flat" (1974).
\end{abstract}

ward goes on to describe a carefully contrived plan outlined by the tenants of Monkwick, in Essex, to purchase the council housing in which they live. Unlike the numerous examples cited previously, the tenants' response was not a "kneejerk" reaction to a shared threat, but a rational approach to what they deemed an unacceptable circumstance.

Their story was recounted in the local paper:

"Council tenants have made a 300 million pound offer to Colchester town council to 
buy the 1000 houses on Monkwick estate. The Tenants' Association... wants to develop the estate as a housing association run on community lines.

"The tenants have worked out that the move would put about 30 shillings a week on the rents, immediately, but payments could be frozen at this figure for five years. They said that the council's fund would gain over 100,000 pounds per year. Instead of receiving about 128,000 pounds a year in rents and government subsidy, they would receive 234,000 pounds a year in mortgages on a 40-year contract....Although private tenants have bought blocks of flats on a co-ownership system, nobody has ever bought an entire council estate" (p. 77).

Thus, the tenants of Monkwick estate purchased their development to empower themselves, yet did so without the sense of urgency that was apparent in ATUH's purchase of University Heights. While unforeseen circumstances (e.g. a slumping housing market) were helpful in ATUH's success, tenants elsewhere may not be as fortunate.

Monkwick, therefore, provides an example of planned tenant organization, of which the principal advantage is an acquisition process unhindered by the hasty mobilization of tenants upon discovering that their tenancy is threatened. Particularly noteworthy is the absence of Edelstein and wandersman's "circumstance theorem". This "better safe than sorry" attitude indicates the importance of a carefully planned tenant acquisition. It is one that should be recognized by tenants of units which are ripe for 
prepayment.

Although legislation (e.g. the Kennedy Bill) mandates reasonable notice of prepayment and priority option to buy reserved for tenants of units threatened by prepayment, Monkwick's success underscore the advantages of planned acquisition as opposed to the ad hoc formation of tenant groups brought together by circumstance.

\section{Tenant Functions}

As Chapter Four discussed the various responsibilities placed upon a tenant organization's leadership, an outline of the role that tenants collectively play is appropriate. Whatever the circumstances of their formation and whatever their makeup, each tenant organization consists of a body of residents who form an essential part of the organization. These roles, as identified by Edelstein and Wandersman (1987), are:

1. Providers of Social Support

2. Sources of Information

3. Sources of Power

These functions will be discussed in the general sense as well as in the context of University Heights.

\section{Social support}

As Edelstein and Wandersman note of the dynamics of mutual tenant support: "In pulling together to address their common problems, [communities] not only build an organization, 
but they build relationships as well" (1987). In this sense, the bond shared by those in a similar situation, i.e. the threat of displacement, becomes an essential means of social and psychological support for tenants.

One of the more interesting points raised by this analysis is the conclusion that those least affected are least likely to become actively involved in an organization. This is not so in the case of $A T U H$, who were made up of a number of tenants from market rate apartments and were not affected by prepayment. Evidence, therefore, indicates that the social support provided by the tenants--particularly longtime residents--is strong. This conflict with Edelstein and Wandersman's findings only indicates that more research is needed to understand the networks and support structures that evolve from the threat of displacement.

In summary, one of the apparent outcomes of threatened displacement is the development of new sources of social support among tenants. This occurs through a phenomenon described as "neighboring, which accompanies and influences the sense of community and participation in a grass roots effort to address the problem" (1987).

Source of Information

One of the inevitable outcomes of mutual social support is the sharing of information. This sharing of information works largely through informal networks, and subsequent rumors 
that were generated often had to be clarified by organization leaders. When asked about their sources of information and their opinion of them during their crisis, the residents of Legler responded that the only source that they considered reliable was the organization's leadership (1987).

This indicates that, when faced by a threat such as imminent displacement, tenants tend to close ranks and lend additional support through the provision of information. When the tenants of University Heights approached the development's previous owners after hearing rumors of prepayment, they were told that no such thing would occur (Platt, 1991). When 48 units were prepaid and it was apparent that the owners did intend to prepay on the remainder of the subsidized units, the beginnings of an elaborate information network were established.

\section{Source of Power}

As noted by Edelstein and Wandersman: "The development of community organizations tends to provide for a new sense of power in the midst of a situation where there is an overall sense of loss of control" (1987). This sense of power, they argue, is apparent at two levels; community power and individual power.

Community power is described as the collective ability to coordinate such essentials as technical support. In other words, by creating a context for social support, a source of 
Individual power is apparent from the numerous growth outcomes that are associated with activism (1987). The transition that some ATUH board members (some of whom are retired) made from the passive role of tenant to the active role of decision-maker may have been "accompanied by enhanced self-worth and personal efficacy" (1987)--a positive occurrence. 


\section{CHAPTER SIX}

\section{CONCLUSIONS}

Although Harry Platt refers to himself and the other members of ATUH as "ordinary people", it is apparent that they are far from ordinary. Besides their display of unique and admirable personal attributes, this is primarily because of the ownership and management structure of the development in which they live. For a number of sociological, political, and economic reasons, an incredibly small proportion of Americans live in homes under social ownership.

One of these reasons is the tradition of the "American Dream", an anachronism carried down in popular culture from a time of economic growth and seemingly unlimited resources. Unfortunately, the American Dream is now an unattainable one for many. One of the results of this is the innovative nonprofit sector that has emerged to lend support to lower income groups who cannot fend for themselves in the depressed economy of the 1990s.

University Heights provides an illustration of some of the non-traditional alternatives (communally-owned housing such as cooperative housing and mutual housing associations) that are being considered. ATUH's reasons for acquiring University Heights underscore the benefits of socially-owned housing, which provides the privacy and security of individual ownership for a more affordable price. 
While it is impossible to determine the direct applicability of ATUH's achievement to the thousands of other subsidized developments throughout the country, a number of characteristics emerged which highlight some of the steps necessary in achieving social ownership. These will be outlined and summarized in this chapter.

\section{Goals Addressed by the Study}

While the threat of prepayment seems unlikely under current economic conditions, this issue must be addressed to prepare tenants of subsidized rental housing for the next real estate boom. This chapter will address the goals that were laid out in the Introduction and discuss them in the context of University Heights and the achievements of ATUH, the wider scope of subsidized rental housing mortgage prepayment, and the functions and conditions that were provided by wireman (1984) and Edelstein and Wandersman (1987).

1. The identification of the major elements behind the successful formation of a tenant organization (or community-based organization) who have won the right to home ownership and the privileges that come with it.

This goal was addressed by the provision of the tenant and leadership functions that were outlined in Chapters Four and Five. Wireman's conditions, combined with Edelstein and Wandersman's tenant functions highlight the principal elements necessary in attaining social ownership. Wireman's conditions served as the framework in describing the critical element in 
ATUH's success--strong leadership. Based on numerous interviews, extensive research of ATUH's methods, and analysis of relevant literature, it is apparent that, of the two principal elements of tenant organization discussed in this study, leadership is more essential.

The detailed analysis of these elements provided in Chapters Four and Five indicate that the principal reason why leadership plays a more active role is largely because the conditions or functions are served most adequately by a small core of active tenants as opposed to a mass of tenants with varying degrees of involvement or interest. It may even be stated with a considerable degree of confidence that key individuals have more influence on an organization's success than the degree of cohesion displayed or functions served collectively by a tenant organization.

This is absolutely the case with ATUH, which paralleled van Eijndhoven and Niewdorp's findings in that ATUH acted essentially without frequent communication with a large proportion of University Heights tenants. Many members-atlarge simply paid their dues but wished to remain anonymous for fear of eviction during ATUH's conflict with the development's previous owners. Furthermore, even among those most active in the acquisition process, Harry Platt appears to have played a central role. An overview of some of these leadership conditions will underscore their greater significance relative to tenant functions. 
With regard to the first condition, the provision of information on an ongoing basis, it is clear that, without some form of hierarchy or chain of command, the organization's direction and motivation may be seriously hindered. Whatever its size, a CBO must have a reference point by which to determine its direction and clarify its goals and objectives. These functions are all served by leaders and have no significant degree of dependence on the mass of tenants that comprise the organization.

The second condition, the availability of trusted technical assistance in understanding complicated or technical programs, also highlights the relative importance of leadership. In this case, the key lies in the representation that is necessary for effective communication between the CBO and those providing their technical assistance.

This is also the case with leadership's regular meetings with decision makers during their deliberations, the third condition discussed by wireman. Representation--provided by the CBO's leadership--is again the key element. As the support of political leaders is of the utmost importance in the complex negotiations involved, the syndrome of "too many Chiefs and no Indians" described by Gans (1962), must be avoided.

Leadership's importance relative to cohesion displayed tenants is again raised when the organization is faced wi the task of proving to both city officials and neighborh 
residents that the organization is representative of the area, the fourth condition. In the case of University Heights, this was achieved by a display of unity among residents of market rate and subsidized units alike. ATUH recognized that only by creating an association serving the best interests of all tenants were they to be viewed as legitimate in the eyes of political leaders, lenders and other key allies. It would be considerably more difficult for a less organized group to take these factors into consideration and have the self-perception to address them.

Finally, the provision of sufficient ongoing stable financial support to relieve a group from spending most of its energies on fund raising, again raises the importance of the coordination provided by tenant leadership. Examples of this are provided by ATUH, who organized the collection of token \$10 membership fees and solicited the assistance of RILS, Project Basic and The Community Builders.

What is most significant about each of these conditions is their illustration of leadership's importance relative to a mere cohesion. The lesson provided by University Heights and ATUH is primarily that a small group of tenants with coordination and focus will achieve more than a large group without these attributes. In other words, an organization's size is of secondary importance to the qualities inherent in its leadership.

The dismal failure of west End tenants to organize 
effectively, as described by Gans, provides an important lesson to tenant organizations. If no leadership qualities (such as communication and organization skills) are displayed among tenants interested in acquisition, they may face considerable obstacles. This is not to say, however, that Edelstein and Wandersman's tenant functions are not important. There role is simply secondary. They supplement leadership, providing support to the organization as a whole, but are by no means indispensable.

This is exemplified by the principles by which saul Alinsky worked in establishing tenant organizations. His strategy presupposed leadership as the CBO's basis and advocated "organizing himself out of a job" (Boyte, 1981).

All relevant case studies (including Gans, Edelstein and Wandersman, Clavel, and Wireman), therefore, indicate that the hierarchical structure which characterized ATUH is the most effective form of organization. The key to the Association's success--the financing necessary to purchase the development-sums up what is really essential and what is superfluous in this regard. RIHMFC did not provide ATUH with financing because the Association was large. The abilities and determination of ATUH board members proved to be the most influential factors in their successful acquisition.

Two major elements behind a successful tenant organization in the case of subsidized rental housing threatened by prepayment can therefore be identified as: 
* an individual or group, with the necessary personal attributes (somewhat extroverted, with strong communication and organizational skills) who will take on a leadership role; and

* circumstances that call for an immediate and drastic response to a threat to the status quo currently enjoyed by tenants.

The second element is obviously disputable. Social ownership does, in fact, take place without the prepayment of 221 (d) (3) mortgages or the expiration of section 8 housing vouchers. However, it can be assumed with reasonable confidence that, unless tenants are directly threatened by prepayment, they will not mobilize. Even laws that have been devised to protect tenants of subsidized rental housing from displacement caused by mortgage prepayments (such as the Kennedy Bill) are a reactive response.

While alternative methods of home ownership are slowly gaining acceptance, the tenants of several hundred thousand subsidized units whose mortgages could be prepaid will more than likely not respond until they face imminent displacement. This was certainly the case at University Heights. As Platt indicated, it was anger and resentment toward the previous owners of University Heights that sparked ATUH's actions.

2. The utilization of identified elements (i.e. leadership and cohesion) as variables by which to evaluate the emergence, development, and eventual success of ATUH.

With specific regard to University Heights, the previously- described elements vary in their applicability. 
While ATUH closely parallels the hierarchic structure characteristic of Love Canal residents described by Edelstein and Wandersman, very few characteristics of "public participation" or "community organization" as discussed by Clavel and wireman are apparent. It can be concluded, therefore, that ATUH conformed closely with regard to the first element--leadership, but very few similarities can be drawn between the case study and tenant cohesion. In sum, it can be derived that the former can flourish without the latter, but the reverse is unlikely.

Keeping in mind the scope of the study--those elements directly influenced and controlled by tenants themselves--the emergence, development and eventual success of ATUH can be solely attributed to leadership. Because of the passive participation of many ATUH members-at-large, tenant cohesion as a collective force had little or nothing to do with the Association's success.

\section{The drawing of conclusions as to what lessons can be learned from ATUH's success and how this success can be simulated in other identified developments throughout Rhode Island.}

One of the principal lessons to be derived from the case is study is preparation. While it doesn't appear likely that real estate speculation will claim any more subsidized units for the time being, tenants should certainly be aware of the implications of prepayment and how they can respond.

In addition, tenants should be aware of what legal 
recourse is available to them. Although ATUH did not follow through with their lawsuit, a new source of tenancy protection was identified. Besides protection from Title VIII of the Fair Housing Act of 1968, as discussed in Chapter Two, the Kennedy Bill also provides protection in that it gives tenants of subsidized rental housing first priority at the purchase of the development if it is offered up for sale.

Several additional lessons are worth noting, as provided by ATUH President Harry Platt.

"First, that a group of tenants with drive determination, and organization can succeed, against great odds, in gaining control of their own housing.

Second, important and timely assistance provided by dedicated nonprofit agencies and organizations is available to tenant groups who wish to take on the challenge of gaining control of their own housing.

Finally, and most important, any group of tenants who work hard and stick together can achieve these same results" (Platt, 1990).

\section{The identification of steps useful to potential tenant organizations based on analysis of elements and subsequent conclusions.}

First, tenants should evaluate the stability of their tenancy. By looking at the indicators which would determine the degree of risk to which a development is exposed, some basic conclusions can be drawn.

Second, tenants should decide whether ownership is worth 
pursuing even if their development is not threatened. The benefits of social ownership exist whether displacement is imminent or not.

Third, potential candidates for tenant organization leadership should be reviewed. If no one among the tenant body will commit themselves, acquisition is unlikely.

Finally, technical support should be actively sought. Several key areas must be addressed. These include real estate and development assistance, legal assistance and community organization assistance. As platt noted, these forms of assistance are available, but must be sought.

In conclusion, it should be noted that ATUH's purchase of University Heights does not mean they lived "happily ever after". In their first meeting since ATUH's purchase of University Heights, Harry Platt noted that ATUH's ownership had presented a whole new set of problems. Platt refers to these problems, however, as "challenges". Despite frequent phone calls at odd hours and the newly acquired task of working out democratic agreements on which cable channels University Heights will receive, Platt and other ATUH members are proud of their achievement and all agree that the benefits of social ownership outweigh the sense of helplessness that characterized the previous phase of their tenancy at University Heights. By their purchase, ATUH were able to prove that the American Dream is still attainable, only in a form more adaptive to minimal government intervention and economic instability. 


\section{SELECTED BIBLIOGRAPHY}

Andrew, Jane. "University Heights tenants celebrate buyout". East Side Monthly. November 1990.

Barfield, Deborah. "RIHMFC okays tenant purchase" Providence Journal-Bulletin. July 1990.

Ms. Janet Billane, Personal Interview, Rhode Island Housing and Mortgage Finance Corporation

Clavel, Pierre. The Progressive City: Planning and Participation, 1969-1984. New Brunswick, New Jersey: Rutgers University Press, 1986.

Chung, Jennifer. "The Potential Reduction in Low Income Housing Stock Due to Federal Subsidy Mortgage Prepayments and Section 8 Expirations: A Look at Rhode Island's Response". Brown University research paper, December, 1988.

Churchman, Azra. "Can Neighborhood Participation in Neighborhood Rehabilitation Programs Succeed?". In Neighborhood and Community Environments. Edited by Irwin Altman and Abraham Wandersman. New York/London: Plenum Press, 1987.

The Community Builders, "Project Descriptions", 1990.

The Community Builders, "Project Listings", 1990.

Conforti, Joseph. "Irving Fain and the Fair Housing Movement in Rhode Island, 1958-1970". (Rhode Island College, 1988).

Davies, J. Clarence. Neighborhood Groups and Urban Renewal. New York/London: Columbia University Press, 1966.

Dykas, Lee. "Preserving a way of life at Heights". Providence Journal-Bulletin. October 12, 1990.

Edelstein and Wandersman. "Community Dynamics In Coping With Toxic Contaminants". In Neighborhood and Community

Environments, eds. Altman, Irwin and Abraham Wandersman. New York and London: Plenum Press, 1987.

Edson, Charles L. "Summary of Low Income Housing Preservation and Resident Home Ownership Act of 1990". Washington DC: Kelley, Drye and Warren. October 24, 1990.

Fawcett, John J. "Providence Redevelopment Agency: Annual Report (s) 1961-1965.

Gans, Herbert J. The Urban Villagers: Group and Class in the Iife of Italian-Americans. New York: The Free Press, 
1962 .

Ms. Denise Hebert, Personal Interview, Rental Agent, University Heights Rental office

Heskin, Allan David. Tenants and the American Dream. New York: Praeger Publishers, 1983.

Hwang, Won-Ki. "Facing the Urban Housing Problems: The Case of the Association of Tenants of University Heights". Brown University, Fall 1989.

Institute for Policy Studies Working Group on Housing (with Dick Cluster). "The Right To Housing: A Blueprint For Housing The Nation". Washington DC: Institute For Policy Studies, 1989.

Jacobs, Jane. The Death and Life of Great American Cities. New York: Vintage Books, 1961.

Jobs With Peace Campaign (JWPC), "What You Can Do To Make the Right To Housing Real". Boston: JWPC National Office.

Mr. Michael Milito, Personal Interview, Project Manager, The Community Builders, Inc.

New England Real Estate Magazine. "Putting The Communities First". November-December 1989.

Platt, Harry. "A roof over your head--when you fight for it". Providence Journal-Bulletin. July 5, 1990.

Mr. Harry Platt, Personal Interview, President, Association of Tenants of University Heights

Providence Redevelopment Agency, "Lippitt Hill Redevelopment Plan (Project No. R.I.R.-3). April, 1959.

Rhode Island Housing Newsletter, Winter 1991, Volume IV No. 1.

Rhode Island Housing. "Rental Housing Production and Rehabilitation Program Guide". January 1991.

Rhode Island Housing. "Strategies For Preserving Rhode Island's Subsidized Housing Stock". 1988.

Spencer, Joseph A. "Tenant Organization and Housing Reform in

New York City: The Citywide Tenants' Council, 19361943." In Community Organization For Urban Social

Change: A Historical Perspective. Edited by Robert Fisher and Peter Romanofsky. Westport, Conn.: Greenwood Press, 1981. 
U.S. Senate. "Summary of S. 566: The Cranston-Gonzalez National Affordable Housing Act". Subcommittee on Housing and Urban Affairs, November 6, 1990.

Ward, Colin. Tenants Take Over. Wellingborough, U.K.: Weatherby Woolnough Ltd. 1974.

Wireman, Peggy. "Community'in the 1980s." In Urban Neighborhoods, Networks, and Families: New Forms for old Values. Lexington, Mass.: Lexington Books, 1984.

Woodward, Alison E. "Public Housing Communes: A Swedish Response to Postmaterial Demands." In Housing and Neighborhoods: Theoretical and Empirical Contributions. Edited by willem van Vliet et all. New York: Greenwood Press, 1987. 

